\title{
PENERAPAN SUPERVISI KUNJUNGAN KELAS UNTUK MENINGKATKAN KINERJA GURU SEKOLAH DASAR NEGERI
}

Oleh : Lisa Nilhuda

Email : $\underline{\text { lisanilhuda@gmail.com }}$

\begin{abstract}
ABSTRAK
Artikel ini dibuat dengan tujuan untuk mengetahui dan memperjelas bagaimana pengaruh supervisi kunjungan kelas terhadap kinerja guru dalam mengajar di kelas. Dalam artikel ini dibahas bagaimana pengaruh supervisi kunjungan kelas itu terhadap proses belajar siswa. Melakuka penelitian dengan menggunakan satu pendekatan yaitu kuantitatif dengan jenis expost facto. Para guru disekolah menjadi subjek penelitian dengan mengambil sampel sebanyak 50 orang guru. Dengan menggunakan teknik proposional ranom sampling dan menggunakan kuisioner tentang pelaksanaan supervisi kunjungan kelas disekolah. Jadi dapat memberikan penjelasan bahwa: (1) ada pengaruh yang signifikan supervisi kunjungan kelas oleh kepala sekolah terhadap kinerja guru, (2) ada pengaruh signifikan terhadap gaya belajar guru dikelas.
\end{abstract}

Kata Kunci : Supervisi Kunjungan Kelas dan Kinerja Guru.

\section{LATAR BELAKANG}

Pendidikan di Negara Indonesia sampai saat sekarang ini dapat dikatakan belunm sesuai dengan keinginan dan harapan negara. Hal ini dikarenakan kurangnya keterampilan, keahlian dan kualitas guru sebagai pendidik dan kualitas tenaga kerja yang bertugas di sekolah. Dan juga disebabkan oleh pesrta didik yang kurang memiliki kualitas yang diri dan lebih suka meneima dari pada menggali ilmu ilmu atau dapat dikatan sebagai siswa banyak yang malas. Hal ini menyebabkan sistem pembelajaran di Indonesia sangat berbeda dengan negara lain, akan tetapi permasalahan tersebut dapat terselesaikan jika supervisi pendidikan memegang peranan yang penting dalam mengingkatkan kuaitas pembelajaran guru yang akhirnya menghasilkan kualitas dan prestasi belajar siswa. Peningkatan sitem pembelajaran dapat dilakukan secara berkesinambungan seiring perkembangan ilmu pengetahuan, teknologi, serta sosial budaya masyarakat. Pendekatan peningkatan kinerja guru sekolah dapat dilakukan dengan teknik Supervisi. 
Supervisi pendidikan adalah suatu pembinaan yang berupa bimbingan atau tuntunan untuk kearah perbaikan situasi pendidikan pada umunya dan untuk meningkatkan mutu tenaga pengajar atau guru dan meningkatkan kualitas belajar pada khususnya agar dapat mencapai tujuan perencanaan pendidikan yang telah disepakati bersama. Seseorang yang bertindak sebagai supervisor harus dapat melakukan pengamatan dan penelitian mengenai situasi sekolah dan juga karyawan-karyawan yang ada dibawahnya. Kegiatan supervisi ini bertujuan supaya supervisor dapat merumuskan problem melalui data yang ada.

Berdasarkan uraian diatas permasalahan yang terdapa di dalam tulisan ini adalah (1). Bagaimana pengaruh supervisi kunjungan kelas terhadap kinerja guru sekolah ?. (2). Bagaiman cara melakukan supervisi kunjungan kelas untuk meningkatkan kinerja guru sekolah i?. Tujuan tulisan ini adalah untuk mengetahui bagaimana pengaruh dan cara melakukan supervisi kunjungan kelas terhadap kinerja guru sekolah.

\section{PEMBAHASAN}

\section{Pengaruh supervisi kunjungan kelas terhadap Kinerja Guru sekolah}

Guru merupakan seorang pendidik profesional yang mempunyai tugas utama mendidik, mengajar, membimbing, melatih, mengarahkan, mengevaluasi dan menilai peserta didiknya guna untuk mencapai tujuan pendidikan. Hal itu sudah diatur dalam Undang-Undang tentang guru dan Dosen. Hal itu menuntut guru harus mampu memahami dan menguasai dengan seksama tugas dan tanggung jawab yang telah diembannya. Dalam pembelajarannya guru juga dituntuk untuk memiliki mutu pengajaran yang baik. Guru yang memiliki mutu yang baik sudah pasti dapat mengaplikasikan ilmunya dengan baik. Dalam upaya peningkatan kualitas guru telah banyak cara yang dilkukan oleh berbagai pihak. Salah satu contohnya melakukan supervisi kunjungan kelas oleh kepala sekolah terhadap guru yang melakukan pembelajaran dikelas.

Supervisi kunjungan kelas merupakan salah satu teknik supervisi yang bersifat individual yang langsung dialkukan oleh seorang supervisor (kepala sekolah) degan cara datang langsung ke kelas dengan melihat, mengamati, mengobservasi cara guru mengajar dikelas untuk memberikan penilain dan pengukuran terhadap kinerja guru dalam mengajar. Selanjutnya bisa dilakukan tindak lanjut apakah perlu diperbaiiki cara mengajarnya atau perlu melakukan pembinaan oleh kepala sekolah.

Sebagaimana diungkapkan dalam jurnal Sabandi Ahmad (2013), dimensi kompetensi-kompetensi supervisi kepala sekolah meliputi : (1) merencanakan program supervisi akademik dalam rangka peningkatan profesionalisme guru, (2) melaksanakan supervisi akademik teerhadap guru dengan menggunakan pendekatan dan teknik supervisi yannng tepat, dan (3) menindaklanjuti hasil supervisi akademik terhadap guru dalam rangka peningkatan profesionalisme.(Sabandi, 2013) 
Supervisi kunjungan kelas bertujuan untuk memperooleh data yang lengkap mengenai guru yangn disupervisi dalam hal melakukakan pengelolaan pembelajaran, dan juga bertujuan untuk memberikan pertoloongan kepada guru untuk melakukan pemecahan masalah dalam menghadapi kesulitan-kesulitan dalam mengajar. Dalam melakukan kunjungann kelas ini yang diutamakan adalah mempelajari sifat dan kualitas cara belajar anak dan bagaimana car guru membimbing peserta didik dalam belajar.

Supervisi kunjungan kelas secara spesifik mempunyai tujuan umum dan tujuan khusus. Tujuan umum supervisi kunjungan kelas adalah untuk mengembangkan kurikulum yang sedang berlangsung atau dilaksankan dan untuk meningkaatkan proses belajar mengajar disekolah. Dan tujuan khusus supervisi kunjungan kelas yaitu untuk memberiikan bantuan kepada guru tantang bagaimana cara mengajar yang baik dan sesuai dengan perencanaan, pelaksanaan dan evaluasi. Dangan adanya supervisi kunjungan kelas memberikan pengaruh yang positif terhadap kinerja guru. Kinerja guru dapat meningkat karena terdapat beberapa arahan, bimbingan dan saran dari kepala sekolah yang bersifat membangun dan terarah.

\section{Cara melakukan supervisi kunjungan kelas}

Sahertian (2002) menegaskan bahwa tujuan supervisi kunjungan kelas ini adalah menolong guru-guru dalam kesulitan-kesulitan yang mereka hadapi. Dalam kunjungan kelas yang diutamakan adalah mempelajari sifat dan kualitas dan cara belajar anak murid dan bagaimana guru membimbing murid - muridnya. Karena sifatnya mempelajari dan mengadakan peninjauan kelas, maka sering disebut observasi kelas.

Supervisi kunjungan kelas juga mempunyai tujuan umum dan tujuan kkhusus. Tujuan umum supervisi kunjungan kelas adalah mengembangkan kurikululm yang sedang dilaksanakan dan juga meningkatka proses belajar mengajar di sekolah. Sedangkan tujuan khusus supervisi kunjungan kelas adalah memberi bantuan dan pelayanan kepada guru tentang cara guru mengajar yang baik dari perencanaan, pelaksanaan dan evaluasi.

Menurut Sahertian (2002) ada beberapa jenis supervisi kunjungan kelas yang dapat dilakukan yaitu sebagai berikut :

a) Kunjungan dengan tanpa memberitahu (Unannounced Visitation)

Supervisi ini dilakukan dengan cara seorang supervisor tiba-tiba datang ke kelas tempat guru mengajar tanpa memberi tahu lebih dahulu. Kelebihan dari supervisi ini supervisor dapat mengetahui keadaan yang sesungguhnya/wajar, sehingga dapat menentukan sumbangan apakah diperlukan oleh guru tersebut. Hal ini dapat membiasakan guru agar selalu mempersiapkan diri dengan sebaik-baiknya. Kelemahan dari supervisi ini menyebabkan guru menjadi gugup, karena tiba-tiba didatangi, hal itu justru menimbulkan prasangka bahwa dia akan dinilai dna pasti hasilnya tidak memuaskan. Ada juga sebagian guru tidak senang, bila tiba-tiba 
dikunjungi tanpa pemberitahuan terlebih dahulu. Berarti supervisi ini hanya mencari kesalahan dari guru.

b) Kunjungan dengan cara memberitahu terlebih dahulu (Anannounced Visitation)

Supervisi ini dilakukan dengan cara supervisor terkebih dahulu memberitahu jadwal kunjungan yang telah direncanakan dan diberikan kepada setiap kelas yang akan dikunjungi, sehingga guru tahu pada hari dan jam yang akan dikunjungi. Jenis supervisi ini juga ada segi positif dan negatifnya. Jika dilihat dari segi positif yaitu adanya pembagian waktu secara merata bagi pelaksanaan supervisi terhadap semua guru yang memerlukannya. Dengan demikian akan dapat tercapainya efisiensi kerja dan meningkatkan proses belajar mengajar. Dan segi negatifnya ada kemungkinan pengurangan kesempatan bagi guru-guru lebih banyak membutuhkan waktu supervisi. Keterbatasan waktu yang ditentukan itu menekan guru yang bersangkutan karena harus mennunggu giliran berikutnya dan para guru dapat mempersiapkan diri dengan sebaik-baiknya karena ia sadar bahwa kunjungan kelas itu akakn membantu apa yang diharapkan.

c) Kunjungan atas Undangan Guru (Visit Upon Invitation)

Pada supervisi ini guru sengaja mengundang kepala sekolah untuk mengunjungi kelasnya. Jarang sekali terjadi ada seorang guru yang menginginkan kepala sekolah melihat/ memperhatikan suasana pada waktu guru tersebut mengajar. Dapat diketahui kelebihan dari supervisi ini adalah supervisor akan lebih berpengalaman dan berdialog dengan guru, sedangkan guru akan lebih mudah untuk memperbaiki dan meningkatkan kemampuannya, karena motivasi untuk belajar dari pengalaman dan bimbingan dari supervisor tumbuh dari dalalm dirinya sendiri. Kelemahan dari supervisi ini menimbulkan kemungkinan sikap manipulasi, yaitu dengan dibuat-buat untuk bisa menonjolkan diri. Dapat menunjukkan ketidaknyataan dari proses yang sebenarnya.

\section{KESIMPULAN}

Berdasarkann pembahasan diatas maka dapat diambil kesimpulan bahwa pelaksanaan supervisi kunjungan kelas oleh kepala sekolah dapat mempengaruhi kinerja seorang guru dalam melakukan proses pembelajaran. Supervisi kunjungan kelas juga merupakan salah satu teknik supervisi yang bersifat individual yang secara langsung dilakukan oleh seorang supervisor (Kepala Sekolah) dengan cara datang langsung ke kelas dengan melihat, mengamati, mengobservasi cara guru mengajar dikelas untuk memberikan penilaian dan pengukurann terhadap kinerja guru dalam mengajar. Selanjutnnya bisa dilakukan tindak lanjut apakah perlu diperbaiki cara mengajarnya atau perlu mendapatkan pembinaan langsung dari kepala sekkolah. 
Supervisi kunjungan kelas juga bertujuan untuk memperoleh data yang lengkap mengenai guru yang di supervisi dalam hal melakukan pengelolaan pembelajaran, dan juga bertujuan untuk memberikan pertolongan kepada guru untuk melakukan pemecahan masalah dalam menghadapi kesulitan kesulitan dalam mengajar. Dalam hal ini yang diutamakan adalah mempelajari sifat dan kualitas cara belajar anak dan bagaimana cara guru membimbing peserta didik dalam belajar.

\section{DAFTAR PUSTAKA}

Sabandi, A. (2013). SUPERVISI PENDIDIKAN UNTUK PENGEMBANGAN PROFESIONALITAS GURU BERKELANJUTAN. Jurnal Pedagogi, Jurnal Ilmiah IlmuPendidikan, XIII(2), 1-9. Retrieved from http://ejournal.unp.ac.id/index.php/pedagogi/article/download/4275/3345 